\title{
Occurrence of COVID-19 in Kolkata slums during second surge
}

\author{
Mukhopadhyay $\mathbf{J}$ \\ Professor, Department of Community Medicine, Jagannath Gupta Institute of Medical Science and Hospital, Kolkata, \\ West Bengal, India
}

Background: The clobber of COVID-19 brought a coup-de-grace to humanity in this modern era. New-norms of COVID-19 prevention although appear promising yet often adjunct with non-congruent compliance. The WHO has advocated house-to-house case-linked study to acquire facts on epidemiological and transmissibility traits of COVID-19 in low-income communities. Kolkata experienced the first wave of COVID-19 till November 20, expected second splatter in March 21. Aims and Objectives: Thinking through a probable upswing of COVID-19 in Kolkata, it was felt prudent to study the occurrence of COVID-19 among residents of two different slums inter-alia study allied factors, if any. Materials and Methods: The study was carried out in two different slums having 395 and 428 members, respectively, in South Kolkata from March 21 to August 21. Sanction was obtained from administrative authority as well from each individual. Questionnaire containing personal details, awareness, and observance of personal protective measures (PPM) on COVID-19 were sent to members through e-mode; those demurred, contacted in-person under new-norm. Data assembled was coded, tabulated and analyzed. Details of COVID-19 (RT-PCR + ve) cases confirmed by Government/private hospitals were incorporated as and when surfaced. Results: Communities studied had comparable socio-demographic attributes including education, employment, and economic stand. About $93 \%$ of subjects from each slum knew most of the facets of PPM and stated practiced the same. Occurrence rates of COVID-19 were 15.2 and 16.2 per 1000 people of respective communities during study tenure. Majority of indisposed were smoker male $(92 \%)$ from the lowest SES $(53.8 \%)$, educated to primary/middle school $(46 \%)$, and worked as vegetable seller $(53.8 \%)$. All afflicted stated followed PPM except social distancing $(77 \%)$ and sanitizer use $(53.8 \%)$. All affected were smokers/quid-users and shared tobacco sticks/hand-smothered quid for mutual use regularly. The study unveiled unequivocal heterogeneity of COVID-19 transmission in Kolkata slums because of certain unattended socio-graphics besides optimistic reflective of PPM awareness/observance. PPM proffers protection no doubt but its effective role necessitates consistent conformity in the background of certain contextual considerations. Conclusion: Further research in urban slums is contemplated to enhance the present effort to extricate facts that may lend a hand in COVID-19 prevention tomorrow.

Key words: COVID-19; PPM; Second surge; Social distancing

\section{Access this article online}

Website:

http://nepjol.info/index.php/AJMS

DOI: 10.3126/ajms.v12i12.39653

E-ISSN: 2091-0576

P-ISSN: 2467-9100

Copyright (c) 2021 Asian Journal of Medical Sciences

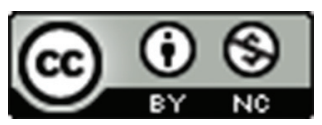

This work is licensed under a Creative Commons Attribution-NonCommercial 4.0 International License.

\section{INTRODUCTION}

The carnage of cankerous COVID 19 has been unprecedented and unheard-of in the history of mankind. Around the world, 216 million have been infected causing 4.45 million fatalities by August 21 with the US leading having estimated 38.5 million cases and India relented for
32.7 million affected. ${ }^{1}$ Low-middle-income countries hold the majority of confirmed cases of COVID-19 with India housing the second-highest number of cases in the world. ${ }^{2}$ Preliminary scientific insights about COVID-19 infection originated chiefly from epidemiological data endorsed in the initial stage of cataclysm in China, ${ }^{3}$ certain European nations, ${ }^{4}$ and North America. ${ }^{5,6}$ Sero-surveillance and 
contact tracing were recommended as critical components of effective public health response to COVID-19 to delineate epidemiological kinetics and transmission dynamics within limited resources in high priority countries. ${ }^{7.8}$ However house-to-house case-oriented study has also been suggested by WHO to generate information on local, epidemiological and transmissibility characteristics of COVID-19. ' COVID-19 spreads in communities through daily chores like contact while running errands, eating together, going to work or meeting friends and family. Adherence to strict public control measures is difficult to enforce, often culminating in community-level susceptibility due to uncontrolled actions and behavior of others. ${ }^{10}$

Kolkata is thickly populated with ever-expansive trade and business, shops, and markets in the vicinity of closenit residential, commercial and shanty settlements with perennial sultry climate perhaps posing strong epidemic threat. Kolkata experienced the first wave of COVID-19 up-till around Nov 2020; has been undergoing ravage of resurgence with escalating cases each day since March $21 .{ }^{11}$

\section{Aims and objectives}

Considering the trend, it was decided to determine the occurrence of confirmed COVID-19 cases in two different slums in Kolkata during the strike of the second surge; apropos study associated factors related to such occurrence if any.

\section{MATERIALS AND METHODS}

The study was conducted from March 21 to August 21 among the residents of two urban slums located in the Tollygang area, South Kolkata having around 100 and 108 families respectively with about 400 members per colony. Access to these slums was facilitated through local administrative body and sanction was secured from the authorities to carry out the study.

The members were interacted at the outset to explain the intent of the study in March 21 and informed individual consents were collected following necessary COVID-19 precautions. Formal list of all members along with address and mobile no. was made. A relevant questionnaire was arranged after revisiting current literature integrating required modifications due to local factors and issues.

The questionnaire comprised of three segments; the first part contained details of personal attributes besides socio-demographic characteristics with job engagement status of the subjects and the second part had details of understanding of personal protective measures (PPM) against COVID-19 with real-life practices for the same. The third section housed facts of COVID-19 infection among residents, in case such surfaced. Socio-economic status (SES) was ascertained as per current scale. ${ }^{12}$ The questionnaire was circulated among few members initially to decide feasibility and modifications if needed.

The final questionnaire was broached to all the members through mobile/electronic media; or else individually (for those not having mobile) in small groups at a time. Any uncertainty in information generated through e-mode was cleared during personal visit. Name, address, and mobile no. of residents were codified for discretion, but the record was preserved to avoid duplication. Name of head of the family and house no. were maintained as primary distinctive identity of the family. New-norm measures such as utilization of mask, hand sanitizer, and social distancing were followed during the interactions. The data acquired was assimilated, tabulated, and statistically validated to infer the outcome.

Communities were monitored for the occurrence of distinct cases of COVID-19 (RT-PCR +ve) affirmed by the Govt/private hospitals/clinics till August 21. Contacts were checked in centres/home for possible secondary attack. Subjects were reinforced again and again the measures for COVID-19 prevention.

\section{RESULTS}

Community 1 and 2 resided in South Kolkata around $1.5 \mathrm{~km}$ apart. Residences were by and large masonry work with asbestos top single room, while few of them were temporary provisional type. Municipal toilets, public water supply, water hand-pumps, and street lights are around but not enough to render public comfort at large. Drainage system is open, littered with undue drop-offs. Surrounding is messy with irregular trash disposal. State hospital and Govt. dispensaries with medical conveniences are nearby for both the slums. Being located in midst of busy vegetable and grocery market, the locality found overpopulated and congested.

Communities included 395 and 428 members, respectively, with sex ratio of 945.8 and 936.6 females/1000 males correspondingly (Table 1). Majority of the respondents belonged to Hindu religion. Employable (21-60 yr.) constituted $68.3 \%$ and $73.4 \%$ of the groups, however in reality $240(60.7 \%)$ and $256(59.8 \%)$ were actually engaged sequentially. Under-20 constituted 27 and 23\% of the communities; family size recounted as 3.95 and 3.96 respectively. 
Majority (38\% and 37.6\%) members of respective groups were educated to primary level as compared to $33.4-35.5 \%$ accomplished middle school (Table 2). 25 and 38 children in respective groups didn't attend school; hence deemed illiterate. Majority of the families (46.3-46.5\%) belonged to lower most SES in contrast to $43.3-44.9 \%$ were from lower middle SES in the corresponding groups.

Nearly $93 \%$ and more members of both the communities knew most of the aspects of COVID-19 infection including benefits of PPM like hand washing with soap and water, use of mask and sanitizer, personal hygiene, social distancing and reporting a doctor/health care facility in case of need (Table 3). Largely these measures were even practiced by the members of both communities in similar proportion matching to their awareness. About 17-18\% subject availed first dose of COVID vaccination. Around $14 \%$ of the individuals from each community even sought health advices as required.

There were 6 and 7 confirmed COVID-19 cases among the subjects of the communities respectively estimating to an occurrence rate of 15.2 and $16.4 / 1000$ of study population in the tenure of the study (Table 4). Subjects from 40 to 49 years age group were mostly (69.2\%) affected; majority $(92 \%)$ were male and smokers belonging to lowest SES group $(53.8 \%)$ generally educated up to primary/middle school (46\% each) working as vegetable vendors (53.8\%). All the affected subjects used mask, washed hands twice a day before meals and observed "no contact greetings" however, only $77 \%$ could follow social distancing and $53.8 \%$ could apply sanitizer. $84.6 \%$ believed contracted the disease at work, however, 23\% were admitted in hospital on diagnosis and recovered uneventfully. About 61.5\% cases occurred in the month of June 21 and contacts of the sick (21 and 23, respectively) got quarantined at home. Children were not affected. All affected and their contacts were tobacco users and exchanged tobacco sticks/quid for mutual puffs/chews regularly.

\section{DISCUSSION}

The age-sex configuration, gender quotient and family size of the communities studied depict mutually comparable features aligning national statistics. ${ }^{13} 240(60.7 \%)$ and $256(59.8 \%)$ members of the communities were engaged in income generation of which $18 \%$ and $20 \%$ tendered by fair gender respectively. Men folk mostly worked as vendors, shop runners, hotel attendants, stall workers and security guards; while females worked as domestic help, hospital ayah/sweeper, or extended hand in the work of their spouse. $365(92.1 \%)$ and 388 (90.7\%) subjects from the communities respectively were literate; that's comparatively higher than documented literacy rate of West Bengal (77\%). ${ }^{14}$ Around $90 \%$ of the subjects hailed from lower-middle and lowermost class of SES. Bare minimum education favoured with small family, trying financial endeavour and meagre social subsistence depicts hardship in human sustenance in Kolkata slums in the face of poor civic facilities.

\section{Table 1: Age, sex, and religion of the subjects}

\begin{tabular}{|c|c|c|c|c|c|c|c|c|c|c|c|}
\hline \multirow{3}{*}{$\begin{array}{l}\text { Age } \\
\text { group } \\
\text { in yrs. }\end{array}$} & \multicolumn{6}{|c|}{ Community 1} & \multicolumn{5}{|c|}{ Community 2} \\
\hline & \multicolumn{2}{|c|}{ Gender } & \multicolumn{3}{|c|}{ Religion } & \multirow{2}{*}{$\begin{array}{c}\text { Total No. } \\
(\%)\end{array}$} & \multicolumn{2}{|c|}{ Gender } & \multicolumn{2}{|c|}{ Religion } & \multirow{2}{*}{$\begin{array}{c}\text { Total No. } \\
(\%)\end{array}$} \\
\hline & Male & Female & Hindu & Muslim & Other & & Male & Female & Hindu & Muslim & \\
\hline $1-10$ & 20 & 24 & 40 & 4 & - & $44(11.1)$ & 26 & 29 & 50 & 5 & $55(12.8)$ \\
\hline $11-20$ & 35 & 27 & 56 & 4 & 2 & $62(15.7)$ & 24 & 20 & 40 & 4 & $44(10.3)$ \\
\hline $21-30$ & 48 & 44 & 92 & - & - & $92(23.2)$ & 58 & 57 & 110 & 5 & $115(26.9)$ \\
\hline $31-40$ & 48 & 46 & 90 & 4 & - & $94(23.8)$ & 53 & 48 & 93 & 8 & $101(23.6)$ \\
\hline $41-50$ & 28 & 26 & 48 & 4 & 2 & $54(13.7)$ & 35 & 32 & 61 & 6 & $67(15.7)$ \\
\hline $51-60$ & 14 & 16 & 28 & 2 & - & $30(7.6)$ & 16 & 15 & 27 & 4 & $31(7.2)$ \\
\hline $61+$ & 10 & 9 & 18 & 1 & - & $19(4.8)$ & 9 & 6 & 13 & 2 & $15(3.5)$ \\
\hline Total & $\begin{array}{c}203 \\
(51.4)\end{array}$ & $\begin{array}{c}192 \\
(48.6)\end{array}$ & $\begin{array}{c}372 \\
(94.2)\end{array}$ & $19(4.8)$ & $4(1.0)$ & $395(100.0)$ & $221(51.6)$ & 207 (48.4) & 394 (92.1) & $34(7.9)$ & $\begin{array}{c}428 \\
(100.0)\end{array}$ \\
\hline
\end{tabular}

Table 2: Education and SES of the subjects

\begin{tabular}{|c|c|c|c|c|c|}
\hline Educational qualification & $\begin{array}{c}\text { Community } 1 \\
\text { Total (\%) }\end{array}$ & $\begin{array}{c}\text { Community } 2 \\
\text { Total (\%) }\end{array}$ & Socio-economic status & $\begin{array}{c}\text { Community } 1 \\
\text { Total (\%) }\end{array}$ & $\begin{array}{c}\text { Community } 2 \\
\text { Total (\%) }\end{array}$ \\
\hline Graduate & $20(5.1)$ & $17(4.0)$ & Upper & -- & -- \\
\hline Secondary & 63 (15.9) & $58(13.6)$ & Upper middle & -- & -- \\
\hline Middle School-VIII Std & $132(33.4)$ & $152(35.5)$ & Middle & $41(10.4)$ & $37(8.6)$ \\
\hline Primary & $150(38.0)$ & $161(37.6)$ & Lower middle & $171(43.3)$ & $192(44.9)$ \\
\hline Illiterate & $30(7.6)$ & $40(9.3)$ & Lower & $183(46.3)$ & 199 (46.5) \\
\hline Total & $395(100.0)$ & $428(100.0)$ & & 395 (100.0) & $428(100.0)$ \\
\hline
\end{tabular}




\begin{tabular}{|c|c|c|c|c|c|c|c|}
\hline $\begin{array}{l}\text { Current knowledge } \\
\text { on COVID-19 }\end{array}$ & $\begin{array}{c}\text { Com-1 } \\
\text { Aware } \\
\text { (No. } \\
\text { and \%) } \\
{ }^{*} n^{1}-351\end{array}$ & $\begin{array}{l}\text { Com-2 } \\
\text { Aware } \\
\text { (No. } \\
\text { and \%) } \\
{ }^{*} n^{2}-373\end{array}$ & $P$ value & $\begin{array}{l}\text { Preventive } \\
\text { measures }\end{array}$ & $\begin{array}{c}\text { Com-1 } \\
\text { Obeyed } \\
\text { No. (\%) } \\
n^{1}-351\end{array}$ & $\begin{array}{c}\text { Com-2 } \\
\text { Obeyed } \\
\text { No. (\%) } \\
n^{2}-373\end{array}$ & $P$ value \\
\hline $\begin{array}{l}\text { Aware of ongoing } \\
\text { COVID-19 spate }\end{array}$ & $\begin{array}{c}326 \\
(92.9)\end{array}$ & $\begin{array}{l}350 \\
(93.8)\end{array}$ & Chi-sq -0.26 , NS & $\begin{array}{l}\text { Taken COVID vac } \\
\text { first dose }\end{array}$ & $\begin{array}{c}61 \\
(17.3)\end{array}$ & $\begin{array}{c}67 \\
(18.0)\end{array}$ & Chi-sq $-0.04, \mathrm{NS}$ \\
\hline $\begin{array}{l}\text { COVID-19 spreads by } \\
\text { cough/sneezing }\end{array}$ & $\begin{array}{c}329 \\
(93.7)\end{array}$ & $\begin{array}{l}352 \\
(94.4)\end{array}$ & Chi-sq - 0.13, NS & $\begin{array}{l}\text { Following cough } \\
\text { sneeze hygiene }\end{array}$ & $\begin{array}{c}329 \\
(93.7)\end{array}$ & $\begin{array}{c}351 \\
(94.1)\end{array}$ & Chi-sq-0.04, NS \\
\hline $\begin{array}{l}\text { COVID-19 causes } \\
\text { death in aged subjects }\end{array}$ & $\begin{array}{l}331 \\
(94.3)\end{array}$ & $\begin{array}{c}349 \\
(93.6)\end{array}$ & Chi-sq -0.17, NS & $\begin{array}{l}\text { Not spitting in public } \\
\text { (Govt. instructions) }\end{array}$ & $\begin{array}{l}330 \\
(94.0)\end{array}$ & $\begin{array}{l}353 \\
(94.6)\end{array}$ & Chi-sq - 0.1, NS \\
\hline $\begin{array}{l}\text { Washing hand with } \\
\text { soap and water helps }\end{array}$ & $\begin{array}{c}333 \\
(94.9)\end{array}$ & $\begin{array}{c}354 \\
(94.9)\end{array}$ & Chi-sq-0.98, NS & $\begin{array}{l}\text { Washing hand with } \\
\text { soap/water twice } \\
\text { a day }\end{array}$ & $\begin{array}{c}329 \\
(93.7)\end{array}$ & $\begin{array}{l}350 \\
(93.8)\end{array}$ & Chi-sq $-0.003, \mathrm{NS}$ \\
\hline $\begin{array}{l}\text { Putting mask while } \\
\text { outdoor helps }\end{array}$ & $\begin{array}{c}329 \\
(93.7)\end{array}$ & $\begin{array}{l}352 \\
(94.4)\end{array}$ & Chi-sq - 0.13, NS & $\begin{array}{l}\text { Using mask while } \\
\text { going out }\end{array}$ & $\begin{array}{c}328 \\
(93.4)\end{array}$ & $\begin{array}{c}352 \\
(94.4)\end{array}$ & Chi-sq - 0.26, NS \\
\hline $\begin{array}{l}\text { Social distancing } \\
\text { keeps off COVID }\end{array}$ & $\begin{array}{l}330 \\
(94.0)\end{array}$ & $\begin{array}{l}353 \\
(94.6)\end{array}$ & Chi-sq $-0.13, \mathrm{NS}$ & $\begin{array}{l}\text { Social distancing in } \\
\text { shops and markets }\end{array}$ & $\begin{array}{l}331 \\
(94.3)\end{array}$ & $\begin{array}{c}352 \\
(94.4)\end{array}$ & Chi-sq - 0.001, NS \\
\hline $\begin{array}{l}\text { Daily bath/personal } \\
\text { hygiene/clothes help }\end{array}$ & $\begin{array}{c}329 \\
(93.7)\end{array}$ & $\begin{array}{l}350 \\
(93.8)\end{array}$ & Chi-sq -0.003 , NS & $\begin{array}{l}\text { Daily bathing and } \\
\text { maintaining hygiene }\end{array}$ & $\begin{array}{c}351 \\
(100.0)\end{array}$ & $\begin{array}{c}373 \\
(100.0)\end{array}$ & --- \\
\hline $\begin{array}{l}\text { Alcohol based } \\
\text { sanitizer disinfects }\end{array}$ & $\begin{array}{c}329 \\
(93.7)\end{array}$ & $\begin{array}{c}351 \\
(94.1)\end{array}$ & Chi-sq-0.04, NS & $\begin{array}{l}\text { Disinfecting hand } \\
\text { with sanitizer }\end{array}$ & $\begin{array}{c}329 \\
(93.7)\end{array}$ & $\begin{array}{l}350 \\
(93.8)\end{array}$ & Chi-sq $-0.003, \mathrm{NS}$ \\
\hline $\begin{array}{l}\text { Hand shake/hugging } \\
\text { help spread }\end{array}$ & $\begin{array}{c}330 \\
(94.0)\end{array}$ & $\begin{array}{c}349 \\
(93.6)\end{array}$ & Chi-sq-0.06, NS & $\begin{array}{l}\text { Not shaking hand or } \\
\text { hugging anyone }\end{array}$ & $\begin{array}{c}330 \\
(94.0)\end{array}$ & $\begin{array}{c}349 \\
(93.6)\end{array}$ & Chi-sq - 0.06, NS \\
\hline $\begin{array}{l}\text { Report a doctor, if } \\
\text { cough, cold and fever }\end{array}$ & $\begin{array}{l}328 \\
(93.4)\end{array}$ & $\begin{array}{c}352 \\
(94.4)\end{array}$ & Chi-sq $-0.26, \mathrm{NS}$ & $\begin{array}{l}\text { Reported to doctor } \\
\text { as and when } \\
\text { required }\end{array}$ & $\begin{array}{c}48 \\
(13.7)\end{array}$ & $\begin{array}{c}53 \\
(14.2)\end{array}$ & Chi-sq - 0.04, NS \\
\hline
\end{tabular}

*Under-10 children were excluded

Nearly more than $93 \%$ from both the communities were familiar with all the facets of COVID-19 aside commonly observed PPM and even practiced the same in similar proportion akin to their awareness. Only $17-18 \%$ of subjects availed first dose of COVID vaccination and $14 \%$ even sought medical advices as needed. It has been documented in the past that substantial no. of subjects were aware about contagiousness (87.3\%), incubation period (57.1\%), and symptoms of COVID-19 (cent percent). ${ }^{15} \mathrm{~A}$ recent work reported that washing hands and use of alcohol-based sanitizer (23.3\%), cough and sneeze discipline along with the use of mask (19.6\%), social distancing (16.1\%), and following all PPM collectively (40.2\%) forestall COVID-19.15 Authors ascribed around $95-98 \%$ of the educated subjects displayed correct preventive knowledge to avert COVID-19 by following PPM. ${ }^{16}$ With $80 \%$ of Indians being employed in non-organized sectors, it is possible that observance of PPM to restrain COVID-19 could be a trying exigent no doubt. ${ }^{17}$ It has been noted that a large no. of subjects followed PPM adequately by using masks $(97.2 \%)$, social distancing (95.3\%), and hand hygiene $(91.2 \%)$ that apparently corroborates the findings of present work. ${ }^{16}$ Strong governmental initiatives coupled with additive effect of awareness, acceptance, and action by the people made it possible to execute public health policies satisfactorily to counter the spikes of COVID-19 infection. ${ }^{18}$
The occurrence rates of COVID-19 were 15.2 and $16.2 / 1000$ population of the community members during the study period. Taking into account the no. of COVID-19 infection as 1.54 and 21.9 million in West Bengal and India correspondingly for the year 2021 as on 31 Aug 21, the occurrence rates work out to 15.4 and $16.5 / 1000$ population in West Bengal and India respectively. ${ }^{19,20}$ Rate of occurrence in present endeavor is comparable to state/ national statistics though the latter could possibly be laced with factors like under-reporting, missing statistics due to comorbidity and diagnostic errors in rural-remote areas in the setting of colossal state and national population.

Large contingent of men from 40 to 49 years assemblage (69.2\%) mostly belonging to the lowest SES group (53.8\%) generally educated up to primary/middle school $(46 \%$ each) working as vegetable vendors (53.8\%) were affected. A study from south India reported that low-income group often suffered higher incidence of COVID-19, implying that COVID-19 may unjustly infect poor class. ${ }^{21}$ All indisposed stated used mask, washed hands before meals, and observed distanced-greetings, however, only $77 \%$ practiced social distancing and 53.8\% used sanitizer.

Tobacco use was generally universal with exchange of tobacco sticks/quid for shared puffs/chews, a sort of habitual customary among vendors/hawkers signifying breach in the protective barrier. Smoking causes goblet cell 


\begin{tabular}{|c|c|c|c|}
\hline Socio-demographic factors & Community 1 & Community 2 & Total (\%) \\
\hline Number of subjects affected & 6 & 7 & $13(100.0)$ \\
\hline \multicolumn{4}{|l|}{ Age group } \\
\hline $40-49$ & 4 & 5 & $9(69.2)$ \\
\hline $50-59$ & 2 & 2 & $4(30.8)$ \\
\hline \multicolumn{4}{|l|}{ Gender } \\
\hline Male & 5 & 7 & $12(92.3)$ \\
\hline Female & 1 & - & $1(7.7)$ \\
\hline \multicolumn{4}{|l|}{ SES } \\
\hline Lower middle & 2 & 4 & $6(46.2)$ \\
\hline Lower & 4 & 3 & $7(53.8)$ \\
\hline \multicolumn{4}{|l|}{ Education } \\
\hline Secondary & 1 & - & $1(7.6)$ \\
\hline Middle school & 2 & 4 & $6(46.2)$ \\
\hline Primary & 3 & 3 & $6(46.2)$ \\
\hline Worn mask & 6 & 7 & $13(100.0)$ \\
\hline Washed hands before meals & 6 & 7 & $13(100.0)$ \\
\hline Social distancing & 4 & 6 & $10(76.9)$ \\
\hline No contact greetings & 6 & 7 & $13(100.00)$ \\
\hline Applied sanitizer frequently & 4 & 3 & $7(53.8)$ \\
\hline Smoking habit & 5 & 7 & $12(92.3)$ \\
\hline Oral tobacco & 4 & 3 & $7(53.8)$ \\
\hline \multicolumn{4}{|l|}{ Occupation } \\
\hline Veg vendor & 4 & 3 & $7(53.8)$ \\
\hline Shop keeper & 2 & 3 & $5(38.6)$ \\
\hline Tea stall keeper & - & 1 & $1(7.6)$ \\
\hline \multicolumn{4}{|l|}{ Suspected place of acquisition } \\
\hline Work place & 5 & 6 & $11(84.6)$ \\
\hline Market & 1 & - & $1(7.7)$ \\
\hline Others & - & 1 & $1(7.7)$ \\
\hline Admitted to hospital & 1 & 2 & $3(23.1)$ \\
\hline \multicolumn{4}{|l|}{ Month of acquisition } \\
\hline May 21 & 3 & 2 & $5(38.5)$ \\
\hline Jun 21 & 3 & 5 & $8(61.5)$ \\
\hline \multicolumn{4}{|l|}{ Quarantine of contacts } \\
\hline Home & 21 contacts of 6 affected & 23 contacts of 7 affected & $13(100.0)$ \\
\hline Center & - & - & - \\
\hline
\end{tabular}

metaplasia justifying increased levels of ACE2 secreted in the lungs of smokers. ${ }^{22}$ Goblet cells are the chief source of mucous that renders a prime barricade to inhaled pathogens preventing subsequent invasion and infection. Though it is possible that smoking increases ACE2 expression in the bronchial epithelium facilitating entry of COVID-19, this does not necessarily indicate a higher risk for developing COVID-19 pneumonia. ${ }^{23}$ A most upto-date research demonstrated that increased cumulative smoking in the past was associated with a higher risk of hospitalization and mortality from COVID-19 in a dosedependent manner. ${ }^{24}$ Exchange/sharing of half-burnt tobacco-stick or hand-smothered tobacco-quid essentially appears an overriding risk for COVID-19 acquisition undoubtedly.

PPM provides essential defensive shield against COVID-19 convincingly but their optimality calls for congruent application in the lore of contextual reflection like discomfort, indistinct communication, shortness of breath, drinking tea, and smoking. ${ }^{25}$ Most gratifyingly children were spared and all afflicted, recovered back to well-being.
Cases surfaced mostly in May-Jun 21 among the subjects, substantiated by national report. ${ }^{20}$

The study showcased the heterogeneity of risks of COVID-19 acquisition prevailing in Kolkata slums in the context of low SES and education, poor civic facilities, crunch of family space and physical environment, sharing of public toilet and water point, marginal workers subsisting on meagre income, working in over-populated high-exposure zone including highrisk cultural dictum that perhaps precludes social distancing and safe-self-sustenance conscience to all possible extent. All these factors contribute, to an extent, higher COVID-19 risk in Kolkata slums through these unattended socio-graphics facilitating social contracting of COVID-19.

The occurrence rates of COVID-19 infection among the communities are reciprocally analogous as well as similar to the state/national figures. Such reflection perhaps indicates that COVID-19 occurrence has probably been influenced by $3^{\text {rd }}$ world socio-graphics in India with millions living 
below poverty line, therefore conveys necessity for further exploration.

\section{Limitations of the study}

This has been a restricted work among the residents of 2 different slums in south Kolkata for a specific time period during heightened surveillance situate with controlled mobility and out-reach under strict containment; therefore the outcome needs cautious interpretation for comparison.

\section{CONCLUSION}

In spite of the confines, the information generated, visualizes that incessant \& unfailing observance of PPM could be most pertinent in this sine-die situation till attainment of vaccination of sizeable population. Health education on safe-self-sustenance considering heterogeneity of causes by tweaking and tuning the awareness parameters would be sine-qua-non to avert COVID-19 undeniably. Further research in similar directions may be of assistance to figure out future line of approach to stall the dread along with vaccination.

\section{ACKNOWLEDGMENT}

JIMSH, IRC for cooperation and assistance.

\section{REFERENCES}

1. WHO Coronavirus (COVID-19) Dashboard; 2021. Available from: https://www.covid-19.who.int. [Last accessed on 2021 Aug 31].

2. Mohanan M, Malani A, Krishnan K and Acharya A. Prevalence of SARS-CoV-2 in Karnataka, India. JAMA. 2021;325(10):10011003.

https://doi.org/10.1001/jama.2021.0332

3. Li Q, Guan X, Wu P, Wang X, Zhou L, Tong Y, et al. Early transmission dynamics in Wuhan, China, of novel Coronavirusinfected pneumonia. N Engl J Med. 2020;382(13):1199-1207.

4. Grasselli G, Zangrillo A, Zanella A, Antonelli M, Cabrini L, Castelli $A$, et al. Baseline characteristics and outcomes of 1591 patients infected with SARS-CoV-2 admitted to ICUs of the Lombardy region, Italy. JAMA. 2020;323(16):1574-1581.

5. Docherty AB, Harrison EM, Green CA, Hardwick HE, Pius R, Norman L, et al. Features of 20133 UK patients in hospital with COVID-19 using the ISARIC WHO clinical characterisation protocol: Prospective observational cohort study. BMJ. 2020;369:m1985.

https://doi.org/10.1136/bmj.m1985

6. Richardson S, Hirsch JS, Narasimhan M, Crawford JM, McGinn T, Davidson KW, et al. Presenting characteristics, comorbidities, and outcomes among 5700 patients hospitalized with COVID-19 in the New York City Area. JAMA. 2020;323(20):2052-2059. https://doi.org/10.1001/jama.2020.6775

7. Fauci AS, Lane HC and Redfield RR. COVID-19-navigating the uncharted. N Engl J Med. 2020;382(13):1268-1269.

https://doi.org/10.1056/nejme2002387
8. Kucharski AJ, Klepac P, Conlan AJ, Kissler SM, Tang ML, Fry H et al, Effectiveness of isolation, testing, contact tracing and physical distancing on reducing transmission of SARS-CoV-2 in different settings: A mathematical modelling study. Lancet Infect Dis. 2020;20(10): 1151-1160. https://doi.org/10.1101/2020.04.23.20077024

9. Coronavirus Disease (COVID-19) Technical Guidance: The Unity Studies: Early Investigation Protocols;2020. Available from: https://www.who.int/emergencies/diseases/novelcoronavirus-2019/technical-guidance/early-investigations. [Last accessed on 2021 Aug 31].

10. Gohil SK and Huang SS. Community COVID-19 incidence and health care personnel COVID-19 seroprevalence. JAMA Netw Open. 2021;4(3):e211575.

https://doi.org/10.1001/jamanetworkopen.2021.1575

11. Second Wave of New COVID cases in Bengal May Peak in MayJun 2021. Times of India, Kolkata edition; 2021. Available from: https://www.timesofindia.indiatimes.com/city/kolkata/secondwave-of-new-covid-cases-in-bengal-may-peak-in-may-jun/ articleshow/81748961.cms. [Last accessed on 2021 Aug 31]. https://doi.org/10.18535/jmscr/v3i9.04

12. Pandey VK, Aggarwal P, Kakkar R and Modified BG. Prasad's Socio-economic Classification-2018: The need of an update in the present scenario. Indian J Community Health. 2018;30(1):82-84.

13. Government of India. Sample Registration system Statistical Report 2010. Office of the Registrar General and Census Commissioner India. New Delhi: Ministry of Home Affairs; 2012.

14. Government of India. Census 2011, Provisional Population Report. Office of the Registrar General and Census Commissioner India. New Delhi: Ministry of Home Affairs; 2012.

15. Pandey S, Gupta A. Bhansali R, Balhara S, Katira P and Fernandes G. Corona virus (COVID-19) awareness assessment-a survey study amongst the Indian population. J Clin Med Res. 2020;2(4):1-10.

https://doi.org/10.37191/mapsci-2582-4333-2(3)-041

16. Shukla $S$ and Deotale P. Knowledge, attitude and practices towards COVID-19 pandemic in the community: A crosssectional web-based survey in India. International J Res Med Sci. 2020;8(10):3652-3656.

https://doi.org/10.18203/2320-6012.ijrms20204246

17. Acharya R, Gundi M, Thoai DN, Pandey N, Patel SK and Pinchoff J. COVID-19-Related Knowledge, Attitudes and Practices among Adolescents and Young People in Bihar and Uttar Pradesh. New Delhi: Report of Population Council of India; 2020. Available from: https://www.popcouncil.com [Last accessed on 2021 Aug 02]. https://doi.org/10.31899/pgy14.1006

18. Tomar BS, Singh P, Suman S, Raj $P$ and Nathiya D. Indian community's knowledge, attitude and practice towards COVID-19. MedRxiv. 2020;2020:1-20. https://doi.org/10.1101/2020.05.05.20092122

19. Corona India Tracker. COVID-19 Cases in West Bengal; 2021. Available from: https://www.coronaclusters.in/west-bengal [Last accessed on 2021 Aug 27].

20. COVID-19 Confirmed, Recovered and Deceased Cumulative Cases in India 2020-21; 2021. Available from: https://www. statista.com/statistics/1104054/india-coronavirus-covid-19daily-confirmed-recovered-death-cases [Last accessed on 2021 Aug 27]. https://doi.org/10.35291/2454-9150.2020.0392

21. Das A, Ghosh S, Das K, Basu T, Das M and Dutta I. Modeling the effect of area deprivation on COVID-19 incidences: A study of Chennai megacity, India. Public Health. 2020;185:266-269. 
https://doi.org/10.1016/j.puhe.2020.06.011

22. Cai G, Bossé $\mathrm{Y}$, Xiao F, Kheradmand $\mathrm{F}$ and Amos $\mathrm{Cl}$. Tobacco smoking increases the lung gene expression of ACE2, the receptor of SARS-CoV-2. Am J Respir Crit care Med. 2020 201(12):1557-1559.

https://doi.org/10.1164/rccm.202003-0693le

23. Polvirano F. Cigarette smoking and COVID-19: A complex interaction. Am J Respir Crit Care Med. 2020;202(3):471-472.

https://doi.org/10.1164/rccm.202005-1646le

24. Lowe KE, Zein J, Hatipoğlu $U$ and Attaway A. Association of smoking and cumulative pack-year exposure with COVID-19 outcomes in the Cleveland clinic COVID-19 registry. JAMA Intern Med. 2021;181(5):709-711.

https://doi.org/10.1001/jamainternmed.2020.8360

25. Chu DK, Aki EA, Duda S, Solo K, Yaacoub $S$ and Schünemann HJ. Physical distancing, face masks and eye protection to prevent person-to-person transmission of SARSCoV-2 and COVID-19: A systematic review and meta-analysis. Lancet. 2020;395(10242):1973-1987.

https://doi.org/10.1016/j.jvs.2020.07.040

\section{Authors Contribution:}

MJ- Concept and design of the study, prepared first draft, analysis and statistical interpretation of result, reviewed literature, prepared and revised manuscript

Work attributed to:

Jagannath Gupta Institute of Medical Science and Hospital, Budge-Budge, Kolkata - 700 137, West Bengal, India

Orcid ID:

Dr. Mukhopadhyay J - (1) https://orcid.org/0000-0002-9470-9453

Source of Funding: None, Conflicts of Interest: None. 